IRA-International Journal of Management \& Social Sciences

ISSN 2455-2267; Vol.05, Issue 03 (2016)

Pg. no. 451-454

Institute of Research Advances

http://research-advances.org/index.php/RAJMSS

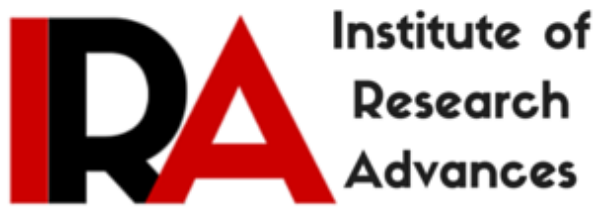

\title{
Smart Phones are a Potential Tool for Successful Business: A Literature Review
}

\author{
Satish Agarwal ${ }^{1}$ \\ Professor, \\ Maharishi Dayanand Saraswati University, Ajmer, India.

\section{Priyanka Bhagoliwal ${ }^{2}$} \\ Research Scholar, \\ Maharishi Dayanand Saraswati University, Ajmer, India.
}

Type of Review: Peer Reviewed.

DOI: http://dx.doi.org/10.21013/jmss.v5.n3.p8

\section{How to cite this paper:}

Agarwal, S., \& Bhagoliwal, P. (2016). Smart Phones are a Potential Tool for Successful Business: A Literature Review. IRA-International Journal of Management \& Social Sciences (ISSN 2455-2267), 5(3), 451-454. doi:http://dx.doi.org/10.21013/jmss.v5.n3.p8

(C) Institute of Research Advances

\section{(cc) EY-NC}

This work is licensed under a Creative Commons Attribution-Non Commercial 4.0 International License subject to proper citation to the publication source of the work.

Disclaimer: The scholarly papers as reviewed and published by the Institute of Research Advances (IRA) are the views and opinions of their respective authors and are not the views or opinions of the IRA. The IRA disclaims of any harm or loss caused due to the published content to any party. 


\section{ABSTRACT}

Smart phones have become a mandatory device to carry now a days. People of all age groups, business category, service class, house wives, students etc need a Smartphone so as to carry their daily routines. From morning alarm to evening engagements, they keep everything in their mobile phone. Meetings, conferences, birthdays and anniversaries, the 'to do list', appointments, emails, documents, notes etc are remembered with the help of a Smartphone. And most importantly, people also carry their mobile charger or a power bank with them. If they do not carry a charger and their mobile phone shows the message that the battery is about to die, it seems as if they do not have enough oxygen to breathe properly. Even in businesses, be it a small scale or a large scale business, Smartphones are used to conduct transactions, video conferencing, conferencing calls, Emails, etc. The paper aims at reviewing the literature on the potential of a Smartphone to make a business successful. It describes how carrying a Smartphone to the work place provides a sense of satisfaction and motivation among the employees.

Keywords- Smart phones, workplace efficiency, Job satisfaction, Employee motivation, knowledge sharing.

\section{Review of Literature}

One of the studies by Drew Hendricks stated that of all the cell phone users, $63 \%$ use cell phone to go online. Drew further stated that for businesses, easy internet access enables employees to stay connected with the presentations, emails, documentaries from anywhere. However there are many disadvantages attached with it. Drew coined that constant connectivity with business will reduce the gap between work and personal life as employees will continuously remain at work during evening hours, weekends as well as on vacations. (Drew Hendricks). Another study by Keith Evans described the advantages and limitations of mobile phones for small business enterprises. As per the study, unlike landline telephones, mobile phones provide more mobility to the users, things become easily accessible and it also provide cost advantage to the small business. The study also described some of the limitations of cell phones. In rural areas, there can be issues of server, network services, data coverage etc. (Keith Evans). Many authors studied the disadvantages of smart phones at work place says that it distract employees from information in important meetings and discussion and may disconnect them from their social circle. ( Ebelhar 2005). One of the studies by Julia describes that some cell phones are so much technologically upgraded that they can perform all the functions which a computer can. Hence it becomes easy to access internet, write emails, or send and receive documents. It increases the flexibility and saves a lot of time and cost incurred in some business transaction. (Julia Forneris). Smartphone are the most handy, easy to use, and compatible device as people carry their personal smart phones with them all the time. (GoogleMobileAds. 2011). Smartphone have become a need in our day to day lives and so the number of smart phone users is increasing. Hence, the companies should not stop their employees from bringing Smartphones at workplace rather they should find alternative uses of smart phone to increase work efficiency. (Smith, A. 2012). Some studies suggest that companies can promote autonomy by providing choices to the employees to bring a mobile phone which they like. This strategy may bring a sense of job satisfaction among the employees and can increase employee's motivation to work efficiently. (Gagne, M. \& Deci, E.L. (2005). Jackson Dawson and Wilson 2003 studied the phenomenon of emails and have claimed that email services increase the work efficiency as well as productivity.

Now a days almost all the companies are using Smartphones as people have become more techno savvy, the companies also believes that Smartphone can help improving the productivity. (Thiraput Pitichat). One study stated that smart phones can be a good tool for sharing knowledge with each other using an internal social networking system so as to make the employees more knowledgeable, efficient, productive and satisfied with the work life. (Miller- Merrell, 2012). The employees don't have to carry their laptops with them any more as smart phones can perform all the functions which a computer can. It is a strong tool for business growth as it provides instant contact wit anyone anywhere anytime and helps employees 
prepare for a presentation or find an answer to some question immediately through the various search engines. (Muhammad Azam).

As per a study by Forestor research, many enterprises go for connected mobile devices support for the employees as well as developing new corporate mobility strategies and policies. The enterprises also support applications for the employees working inside and outside the office. The applications used are Tracker, GPS, mobile expenses and time sheets. Employees also use Smartphones as a platform for communication with internal and external public as it is easy to use and hassle free. (Chow, Chen, Yeow and Wong 2012). There are also indirect impacts of using m-banking, m-payments, in a way that It could bring more money in to the banking industry, and upgrade the taxation system. (Donner, Jonathan and Tellez, Camilo.,2008).

\section{Conclusion}

We are in such a tech savvy business world where the corporate sector is greatly benefited with Smartphones. Every industry, be it large or small, every institute, every organization, hospitals, schools, etc are using Smartphones for some or the other purpose. Because of the faster internet speed and easy accessibility, smart phones have become a very useful tool for business. The various applications used by the corporate world are Whatsapp, Gmail, SMS, GPS Navigator, Tracker, Camera and search engines. It is a fastest networking tool a person can broadcast and send notification to a group. The Telecom Regulatory Authority of India, TRAI, introduced enhanced bandwidth so that it become more faster and improve the quality of data transmission, resulting Reliance "Jio". Smartphones these days are also used by the architecture industry. The civil designers and contractors are using Virtual Reality devices to build mega structures. These VR devices gives a reality view with which one can visualise and experience the virtual tour and examine how things will be. Smartphones are used in banking industry for various transactions. Smartphones have simplified the transactions of banking sector and it saves a lot of time resulting in improved work efficiency and job satisfaction of employees. In the insurance sector also, smart devices are used to convey the information about new policies, inform the customers about their due premium and faster communication to the root level employees. The firms are supporting the use of Mobile phones, Applications and Services because of their mobility. Some more benefits of using Smartphones in business are increased worker productivity, reduced fuel and maintain cost, improved customer satisfaction, reduced sales cycle time, reduced inventory cost etc. This paper concludes that Smart phones have the potential to build healthy business relationships, promote autonomy, maintain work flow, share knowledge and provide job satisfaction to the employees. It is a great tool to improve work efficiency of the employees.

\section{References}

1. Chow, M.M., Chen, L.H., Yeow, J.A., \& Wong, P.W. (2012). Conceptual Paper:Factors Affecting the Demand of Smartphone among Young Adult. International Journal of Social Science, Economic and Arts , 2(2), 44-49.Creswell, J. (2007).

2. Donner, Jonathan and Tellez, Camilo. (2008). "Mobile banking and economic development: Linking adoption, impact, and use", Asian Journal of Communication, 18(4), 318-322.

3. Drew Hendricks, 7 ways mobile will change business in 2014, Forbes/ Entrepreneurs, October 29,2013, http://www.forbes.com/sites/drewhendricks/2013/10/29/7-ways-mobile-will-changebusiness-in-2014/\#7dba5dc76cb7).

4. Ebelhar, J. (Jun 21, 2009). Mind your BlackBerry or mind your manners. The New York Times.

5. Forrester research, A custom Technology Adoption Profile Commissioned By Cisco Systems, "The Expanding Role of Mobility in the Workplace" February 2012, www.foresster.com 
6. Gagne, M. \& Deci, E.L. (2005). Self-determination theory and work motivation. Journal of Organizational Behavior. 26, 331-362.

7. GoogleMobileAds. (2011) Voice of the Smartphone user: South Korea. www.youtube.com, Retrieved from http://www.youtube.com/watch?v=3j_2srh7o3M\&feature=plcp

8. Jackson, T. W., Dawson, R. A. Y., \& Wilson, D. (2003). Understanding email interaction increases organizational productivity. Communications of the ACM, 46(8), 80-84.).

9. Julia Forneris, Advantages of cellular phones in business, http://smallbusiness.chron.com/advantages-cellular-phones-business-4016.html

10. Keith Evans, Advantages and Disadvantages of cellphones, http://smallbusiness.chron.com/advantages-disadvantages-cellphones-business-57421.html ).

11. Miller-Merrell, J. (2012). The workplace engagement economy where HR, social, mobile, and tech collide. Employment Relations Today. n.d. 1-9.

12. Muhammad Azam, Role of Smartphones in Businesses, Business to community, September 24, 2014, http://www.business2community.com/mobile-apps/role-Smartphones-businesses01012882\#wFOACQqFWxxhIEAv.97

13. Smith 2012, Smith, A.(2012). $46 \%$ of American adults are Smartphone owners phones within, Pew Research Center's Internet \& American Life Project. Retrieved from http://pewinternet.org/Reports/2012/Smartphone-Update-2012.aspx )

14. Thiraput Pitichat, 2013, Smartphones in the workplace: Changing organizational behavior, transforming the future, LUX: A Journal of Transdisciplinary Writing and Research from Claremont Graduate University, Volume 3 | Issue 1, Article 13 